University of the Pacific

Scholarly Commons

University Libraries Librarian and Staff Articles and Papers

University Libraries

$6-2020$

\title{
Curating Knowledge, Creating Change: University Knowledge Center, Kosovo National Transition
}

\author{
Mary M. Somerville \\ University of the Pacific, msomerville@pacific.edu \\ Anita Mirijamdotter \\ Linnaeus University, anita.mirijamdotter@Inu.se \\ Edmond Hajrizi \\ University for Business and Technology - UBT, ehajrizi@ubt-uni.net \\ Elham Sayyad Abdi \\ Queensland University of Technology, e.sayyaddabdi@qut.edu.au \\ Michele Gibney \\ University of the Pacific, mgibney@pacific.edu
}

See next page for additional authors

Follow this and additional works at: https://scholarlycommons.pacific.edu/libraries-articles

Part of the Higher Education Commons, and the Library and Information Science Commons

\section{Recommended Citation}

Somerville, M. M., Mirijamdotter, A., Hajrizi, E., Sayyad Abdi, E., Gibney, M., Bruce, C., \& Stoodley, I. (2020). Curating Knowledge, Creating Change: University Knowledge Center, Kosovo National Transition. IFLA Journal, 46(2), DOI: 10.1177/0340035219883897

https://scholarlycommons.pacific.edu/libraries-articles/113

This Article is brought to you for free and open access by the University Libraries at Scholarly Commons. It has been accepted for inclusion in University Libraries Librarian and Staff Articles and Papers by an authorized administrator of Scholarly Commons. For more information, please contact mgibney@pacific.edu. 


\section{Authors}

Mary M. Somerville, Anita Mirijamdotter, Edmond Hajrizi, Elham Sayyad Abdi, Michele Gibney, Christine Bruce, and lan Stoodley 


\title{
Curating Knowledge, Creating Change: University Knowledge Center, Kosovo National Transition
}

Mary M. Somerville, University Librarian, University Libraries, University of the Pacific, United States

Anita Mirjamdotter, Professor, Department of Informatics, Linnaeus University, Sweden

Edmond Harjizi, President, University for Business and Technology, Kosovo

Elham Sayyad-Abdi, Fulbright Scholar-in-Residence, University of the Pacific, School of International Studies, United States

Michele Gibney, Head of Publishing and Scholarship Support, University of the Pacific., University Libraries, United States

Christine Bruce, Dean, Graduate Research, James Cook University, Australia

Ian Stoodley, Coordinator, Library and Information Education, School of Information

Systems, Science and Engineering Faculty, Queensland University of Technology, Australia

\begin{abstract}
A collaborative system design initiative at the University for Business and Technology in Kosovo aims to make local knowledge visible and to enhance local knowledge creation, within the university and throughout the country. Since its inception in 2015, design activities aimed to activate systems through modeling the global knowledge landscape, technology enabled systems, and human activity processes. Within the framework of Informed Systems, application of Informed Learning theory and Information Experience Design (IXD) guided prototyping systems that informed building an institutional repository named UBT Knowledge Center. The knowledge vision anticipates that sustained curation, organization, discovery, access, and usage processes will accelerate academic engagement, national development, and global visibility, over time and with practice to further theory-to-practice and practice-to-theory.
\end{abstract}

Key words: Informed Systems, Informed Learning, Information Experience Design, Soft Systems Design, co-design, Kosovo

\section{University for Business and Technology Context}

In 2008, Kosovo unilaterally declared its independence from Serbia. The country has since gained diplomatic recognition as a sovereign state by 112 United Nation member 
states. This change in status accelerated Kosovo's transition from an agricultural economy to a knowledge economy, without industrial age encumbrances.

To develop Kosovo's knowledge economy, the University for Business and Technology (UBT) was founded in Pristina in 2001. Educational programs grant bachelor and master degrees in a variety of subjects, including mechatronics, computer science, integrated design, engineering, economics, architecture, public policy, law, and medicine (University for Business and Technology, 2019a). The curriculum aims to favorably position Kosovo industries in European knowledge and labor markets. UBT has seen bold growth, since its initial offering of one Master's program in engineering management for 28 students. Now 15 Faculties offer 32 accredited academic programs and 84 majors, which anticipate workforce requirements in an increasingly digital, global world. Disciplinary curricula delivered on five campuses to 17,000 students is enriched by 40 research labs, 7 research institutes, and 20 research centers which investigate national and regional issues, producing more than one thousand publications each year. Such a robust intellectual milieu results in workplace ready graduates, as evidenced by a high placement rate.

Showcasing scholarly intellectual productivity, the founder and president recognized several years later, requires that research productivity and creative work must be discoverable if it is to be usable within the university and beyond. In response, he engaged UBT computer science students in programming a platform, named RIIMS (University for Business and Technology, 2019b), to present bibliographic references for faculty publications. The software was then shared with the Ministry of Education for use by all institutions of higher education in Kosovo, as a national academic database with multiple access points at individual, institutional, and national levels. To further stimulate intellectual productivity, the University also initiated an annual international conference in 2011 to foster dialogue and collaborations among UBT faculties and international researchers. From these early beginnings, a Knowledge Center concept evolved, in response to growing recognition that the University lacked systemic processes and information practices for curation, organization, discovery, use and preservation of local scholarship. [Note: Indicative of the problematical situation, as of August 2018 - before the implementation of the Knowledge Center institutional repository, Scopus listed only four UBT publications and Web of Knowledge listed only one UBT paper, which demonstrates absence of visibility and, hence, paucity of discovery and usage.]

\section{UBT Knowledge Center Evolution}

Over the years, the conceptualization and implementation of a Knowledge Center has assumed increasing importance for this relatively young university in an even younger country. As stated in the UBT Knowledge Center vision, "the University for Business and Technology intends to build collaboration environments to enable discovery and access, interpretation and analysis, creation and sharing of knowledge" (Hajrizi, Mirijamdotter, Salavati, \& Somerville, 2017a, p. 1). This aspiration quite naturally led to exploration of possible approaches to advance a knowledge center to further local knowledge visibility and advance local knowledge creation. 
The initiative addresses IFLA Global Vision values and goals, which foster innovative practices and tools, shared expertise and resources, and resilient systems and solutions to provide access and ensure preservation of the world's documentary heritage (IFLA, 2018).

In order to advance the knowledge vision and further this thought leadership, an Informed Systems approach (Somerville, 2015a, 2015b) was adopted and adapted by University for Business and Technology. Significantly, this theoretical framework advances information literacy, interpreted as the experience of using information to learn (Bruce, 2008) during systems design and within designed systems. The approach evolved since 2003 in North America, through contributions from a distributed team of multi-disciplinary researchers working in Europe, Australia, and North America. Informed Systems draws antecedent theoretical insight from Informed Learning theory which values variation in information experience and use to enrich awareness and promote learning (Bruce, 2008), thereby advancing information literacy. It further draws upon information experience theory (Bruce, Partridge, Hughes, Davis, \& Stoodley, 2014; Somerville \& Mirijamdotter, 2014) and, more specifically, Information Experience Design research and design phases (Sayyad-Abdi, 2017). These information centered elements are paired with human centered Soft Systems Methodology design tools that can situate and evolve systems within ecosystems (Checkland \& Poulter, 2006, 2010). Within this rich theoretical and methodological construct, Informed Systems acknowledges the learning efficacy of systems design and designed systems. In so doing, an Informed Systems initiative enables learning through use of information in different ways, during design and following implementation, thereby enriching practice and theory of Informed Learning.

At its essence, Informed Systems is a participatory approach for system co-design with and for users. These systems enable learning through use of information during the design, for beneficiaries and stakeholders involved in the design process for the system and within the built environment for system users. The simultaneous emphases on 'user', 'system', 'technology', and 'learning' made Informed Systems a particularly suitable theoretical background for the Knowledge Center, which aims to transform knowledge generation at a Kosovo university. The Informed Systems theoretical construct also encouraged customization of this inclusive approach to the local circumstances and cultural perspectives of the primary stakeholders, who serve as co-designers and co-learners (Somerville, 2015b).

As Informed Systems initiatives in the United States from 2003 to the present have demonstrated (Somerville, 2009; Somerville, 2014; Somerville, 2015a; Somerville, 2015b; Somerville \& Mirijamdotter, 2014; Somerville, Imhof, Bruce, \& Sayyad-Abdi, 2017; Somerville, Mirijamdotter, Bruce, Chaudhary, \& Salavati, 2018; Somerville, Chaudhary, Mirijamdotter, \& Sayyad-Abdi, 2019), collective learning is progressed through information experiences that acknowledge content, the information itself, and context. Collective learning thereby promotes interrelationships between people and their environment. Over time, robust exchange relationships advance the sharing of information, skills, expertise, and experience with the aim of establishing common ground and shared practices that evolve local values and performance behaviors. This inclusive and emancipatory approach, which underpins the Kosovo initiative to 
further institutional and national aspirations, evolved through contributions from a distributed interdisciplinary (Gibney, Mirijamdotter, Somerville, Elm, \& Pireva, 2018) and international (Somerville, 2015c) research team with contributors from Sweden, Australia, the United States, and - since 2015 - Kosovo.

The paper presents an original application of Informed Systems through a theory-to-practice initiative. It also, through explanation of this implementation, furthers appreciation for its practice-to-theory contributions. Within an Informed Learning (Bruce, 2008) lens, Information Experience Design (IXD) research and design phases (Sayyd-Abdi, 2017) guide the inception and expression of a UBT Knowledge Center. Soft Systems Methodology (Checkland \& Poulter, 2006, 2010) tools situates and visualizes the initiative within a global knowledge ecosystem. In these ways, Informed Systems catalyzes local knowledge creation and learning practice during systems design and for systems users (Somerville, 2015a; Somerville, Mirijamdotter, Bruce, Stoodley, \& Pireva, 2018). Results enrich understanding of nuanced aspects of theory to practice and practice to theory, which culminates in recommendations for Knowledge Center enhancements to more fully experience Informed Learning.

\section{Ecosystem Modeling}

Initial design activities for the UBT Knowledge Center commenced with modeling the knowledge ecosystem in which students lived, worked, and studied. In the spring semester of 2017, 3 instructors, 2 from Sweden and 1 from the United States, facilitated a one-week course in which 10 graduate students in information systems co-created their collective understanding of the institutional knowledge context, within a national and international context. Assigned readings preceded course commencement, and final reports were due several weeks after course meetings, to ensure ample time for preparation and reflection.

Also drawing from the systems sciences, the course used the Soft Systems Methodology (SSM) 'Rich Picture' technique to enable students to represent collective perceptions of the current information landscape for the University and for Kosovo, within the larger global scholarly communications network. A Rich Picture technique aims to "capture, informally, the main entities, structures and viewpoints in the situation, the processes going on, the current recognized issues and any potential ones" (Checkland \& Poulter, 2010, p. 210). This modeling tool recognizes that: "The complexity of human situations is always one of multiple interacting relationships. A picture is a good way to show relationships.... 'This is how we are seeing your situation. Could we talk you through it ...?'” (Checkland \& Poulter, 2010, p. 209).

Students contributed to the UBT Knowledge Center concept through working in groups guided by systems thinking processes and techniques and fortified by conceptual understandings about information, research, and scholarship. As the Framework (Association of College \& Research Libraries, 2015) states: "Information literacy is the set of integrated abilities encompassing the reflective discovery of information, the understanding of how information is produced and valued, and the use of information in creating new knowledge and participating ethically in communities of learning" (p. 8). Informed Learning information literacy practice fostered through engagement with the campus community provided rich opportunities to both 
explore and practice information literacy, in the spirit of Informed Learning which encourages simultaneous attention on discipline content (systems sciences) and information use (Hughes \& Bruce, 2010). Analysis of mixed methods data also fostered students' appreciation for relationality, as expressed through the multiple ways that others use information to learn (Hughes \& Bruce, 2010). When expressed as ACRL Framework concepts, students gained deep insights into information creation as a process, research as inquiry, and scholarship as a conversation, which subsequently guided their systems design efforts.

Various UBT Knowledge Center models emerged from these student studies on information use and information landscape. One group model emphasized four aspects: library (physical library), electronic archive (e-archive), globalization platform, and online communication (Aliu, Bllacaku, \& Shkodra, 2017). A second group developed library use scenarios that informed their visualization of the university's Knowledge Center concept. Drawing from focus groups and personal interviews with professors, administrators, information technologists, librarians, and students, students concluded that the initiative "is a great idea that will change how we see and treat knowledge in the future" (Kasemi, Lushta, \& Rexhepi, 2017). The third group perceived the whole UBT Innovation Campus as the Knowledge Center. They modeled an attractive, inclusive physical space for worldwide communication and learning materials to foster student learning, faculty teaching, and university research. They considered 'the whole life' of the student, such as the need for day care and need of nice surroundings to support creativity, besides having study materials and other resources for professor and peer exchange and cocreation (Xhemajli, Rexhepi, Sejdiji, \& Arifi, 2017).

The Figure 1 composite Rich Picture illustrates UBT students' visualization of the Knowledge Center landscape. It represents physical and virtual 'places and spaces' for the human activities and interactive relationships that animate information exchange for knowledge creation. Further, the Rich Picture acknowledges the academic library collection - 200,000 print books, as well as e-books and publisher databases - represented as global 'core knowledge' to be complemented by situated 'local knowledge'. 


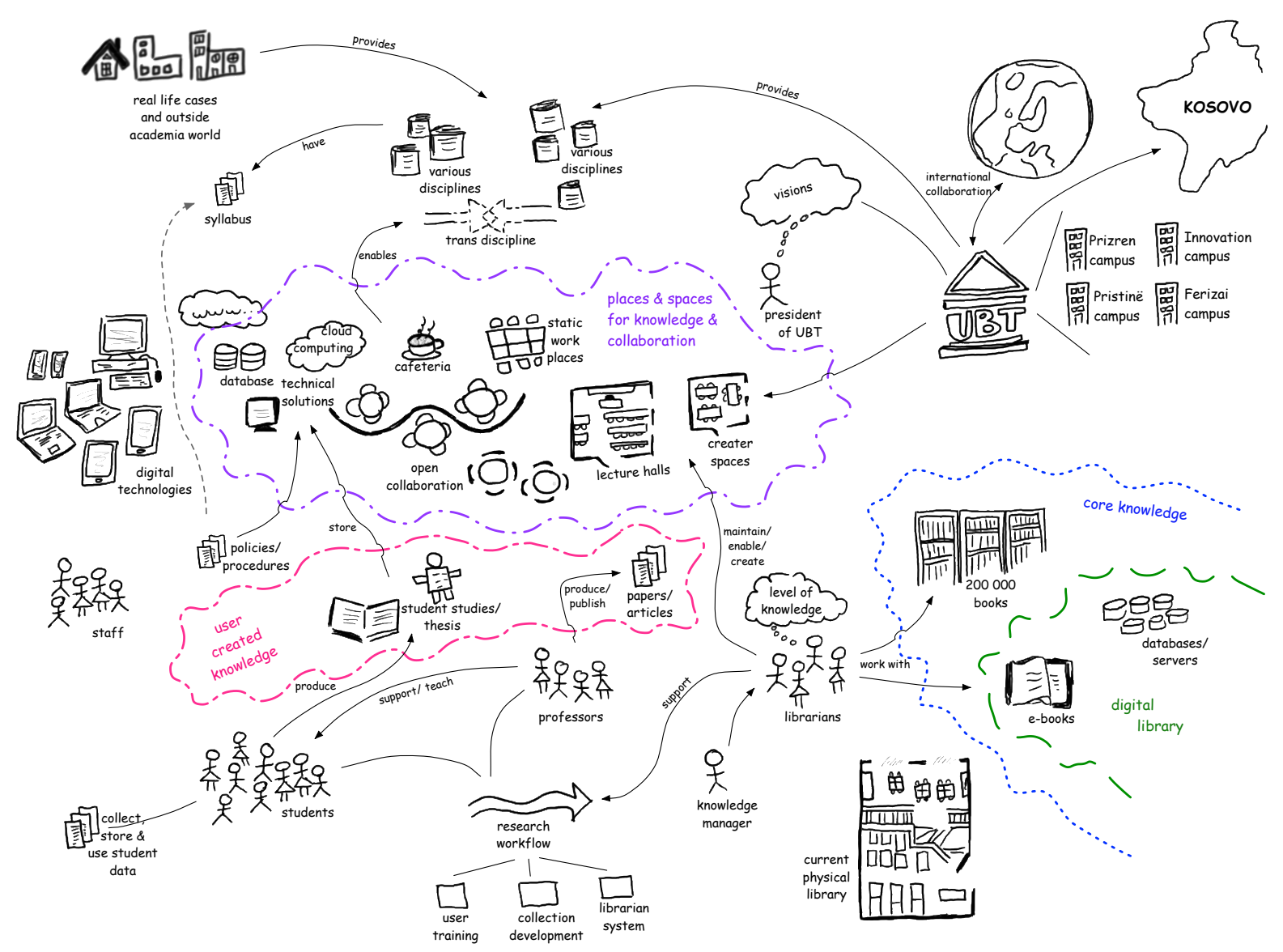

Figure 1. Composite UBT Knowledge Center Rich Picture CC-BY 4.0 (Mirijamdotter, Somerville, Salavati, et al., 2018)

Student evaluations confirmed the efficacy of a Rich Picture visualization tool for representing the multiple relationships within a whole system deemed problematical, with the aim of improving it (Mirijamdotter, Somerville, Salavati, \& Hajrizi, 2018. In that spirit, they asked questions about the situation, which promoted further conversation and deepened collective questioning, and subsequently required redrawing. In other words, pictures aided reflection, advanced thinking, and enriched dialogue - prompting the need for additional modeling to capture changes. Students also noted significant learning, including identification of "three essential parts of a holistic Knowledge Center ecosystem: a digital environment to advance local knowledge visibility, an organizational environment to enhance boundary crossing collaboration, and a digital academic library environment to enable discovery of and access to published academic scholarship" (Hajrizi, Somerville, \& Mirijamdotter, 2017b, p. 2). These 2017 
course learning outcomes constituted the starting point for the 2018 spring course, which advanced the Knowledge Center concept through prototyping.

\section{Information Experience Design}

In Spring 2018, earlier Informed Systems results were enriched through Information Experience Design (Sayyad-Abdi, 2018; Bruce, Partridge, Hughes, Davis, \& Stoodley, 2017) activities. IXD has its origins in Informed Learning (Bruce, 2008), which attends to the varying experience of information use, wherein what constitutes information takes different forms and varies within disciplines and communities (Bruce \& Hughes, 2010), IXD encourages variation in experience of information use to learn to design variation in information use, in this instance within information focused and human centered systems. Through becoming more able to use information in a wider range of ways, co-designers advance their information literacy during systems design and within the designed systems, as conceptualized in Informed Systems.

The course was taught by four instructors, 2 from Sweden and 2 from the United States. In total, 34 undergraduate computer science and graduate information systems students participated, guided by the Informed Systems engagement principle for and with users. During the research phase preceding the design phase, students explored the variation in their academic information experience, with a special focus on local scholarship use. Building on the ACRL Framework (2015) information literacy concepts introduced in the Spring 2017 course, students again used mixed methods to explore: information creation as a process, research as inquiry, and scholarship as a conversation. Required readings preceded the course start, to ensure individual preparation, and final projects were due several weeks after course meetings, to complete group work. In addition, a reflections assignment advanced the Informed Learning reflection concept, which encompasses both the "experience of information literary (learning) and reflection on experience (being aware of learning)" (Bruce \& Hughes, 2010).

Course activities were guided by Informed Learning, the antecedent theory for both Informed Systems and Information Experience Design, which simultaneously focuses on information use and learning. Instructors presented the seven qualitatively different ways of experiencing information and information use, including the relationships between information and its contexts of use (Bruce, 2008), to promote Kosovar students' recognition of variation in information literacy, among their classmates and within their research subjects, with the twofold aim to advance information literacy among system users and to enhance information experience for system users. The seven Informed Learning classifications range from technologies, sources, and processes, to curating, organizing, and generating (new) knowledge, aimed at societal benefit. See Appendix A for a fuller description of the informed systems categories.

In adopting an Informed Learning lens within this course, instructors asked students to recall stories about how they used information to learn. Such student stories required "being aware of the kinds of information we are using, how we are using information and how different forms of information come together to inform and transform" (Bruce, Hughes, \& Somerville, 
2012 , pp. 8-9). Then, to enliven shared vision and advance common purpose, students worked in groups to visually represent collective academic research experiences. This initial exploration of the relationship between information and the context of its use revealed that students only experienced the first three Informed Learning categories in their knowledge practice.

1. Information and communication technologies: Harnessing technology for information and knowledge retrieval, communication, and management;

2. Information sources: Using information resources (including people) for academic learning and action taking;

3. Information and knowledge generation processes: Developing personal practices or heuristics for finding and using information for novel situations (Bruce, Hughes, \& Somerville, 2012).

Students' Rich Picture drawings were then shared with classmates to clarify common patterns. Results revealed that while students typically used academic library resources from global academic publishers, they never used content produced by their UBT peers or professors. As one student group had expressed the dilemma during the spring 2017 course:

"You are part of an institution and you are willing to generate some knowledge, but have no way of storing it or sharing it; or you're looking for some important information that would have helped you on your work but you have no way of reaching it" (Hajrizi, Ramadani, Bivolakum, Gosalci, \& Konushefei, 2017c).

The next phase of the Information Experience Design process aimed to address problems that students identified through analysis of their information use stories, which revealed the absence of higher-level Informed Learning categories. In response, students designed system prototypes with curation and management processes to advance local knowledge visibility, access, and usage through intentional relationships and designed practices. To capture, organize, and use local knowledge to produce more local knowledge, students sought to 'bridge' individual learning capability and collective learning capacity, which was absent in their narrative stories.

Students were also introduced to another Soft Systems Methodology tool, PQR (Checkland \& Poulter, 2006, 2010), which aimed to further another 2017 aspiration for "connections with others to create knowledge" as "producers of something useful to society" (Hajrizi, Ramadani, Bivolakum, Gosalci, \& Konushefei, 2017c). Students' collective inquiry started with exploration of these questions: Why do it? (SSM R), What to do? (SSM P), and How to do it? (SSM Q).

In answer to Why?, students recognized that the curation, organization, discovery, access, and preservation of UBT knowledge could increase university impact within higher education and civic society. Co-designed systems and workflows for information exchange could improve local knowledge conditions and thereby increase both Albanian and English language content creation. 
In considering What?, students envisioned the curation of faculty papers, faculty presentations, student research studies, and student creative work, such as architectural renderings, 'recycle engineering' inventions, and robotics prototypes. They further recommended designing robust relationships through human activity systems among and between Kosovar and global research communities.

To activate How?, students fostered information experience elements, including Informed Learning categories 1-3 (technologies, sources, and processes), which underpin Informed Learning category 4 (information curation and knowledge management) (Bruce, Hughes, \& Somerville, 2012). Prototyping processes included modeling how students use information to learn and how they could better use information to learn, within enabling systems and with associated practices.

These explorative questions guided collective thinking about how and why to save information, share information, and use information - the what - through a well-structured online platform to offer easy access, update knowledge assets, and manage information flow. Interestingly, student-generated outcomes of this phase aligned with the fourth Informed Learning category, which forms a bridge from categories 1-3 to categories 5-7:

4. Information curation and knowledge management: Organizing and managing data, information, and knowledge for future academic needs (Bruce, Hughes, \& Somerville, 2012).

Following the design phase of the IXD approach, the outcomes of this phase, supported the identification of specifications, including the system-in-design features and functions, to further the enablement of Informed Learning within the Knowledge Center through a more holistic information experience that advanced the fourth Informed Learning category.

Information Experience Design aims to enable Informed Learning, during both the research phase described above and the design phase explained below, through fostering increasing variation. Since students reported experiencing categories 1-3 but not experiencing category 4 , they naturally recommended platform features and functions for more variety in the experience of using information. They understood that enablement of the experience of the fourth category of Informed Learning, information curation and knowledge management, would thereby increase information literacy.

\section{System Requirements}

During the 2018 course, students identified and expressed system requirements for an institutional repository that would bridge Informed Learning concepts 1-3 through a fourth concept leading to the completion of the cyclical research process in concepts 5-7. A repository's primary functions are curation and management, to support and stimulate a research culture, which aligns precisely with Informed Learning category 4 . The University 
President attended student presentations and heard their repository recommendations, which subsequently guided the University's selection of an institutional repository platform.

Starting in May 2018, multiple discussions considered the needs of UBT with regard to an institutional repository, mindful of students' insights. Decision makers - including the University President, 2018 course instructors, and UBT technology staff - considered whether it would be better to create an entirely new system, use an open source option, or purchase a hosted solution. It was ultimately decided to pursue a hosted solution which would allow for institutional resources to focus on content population rather than system maintenance. UBT purchased a bepress Digital Commons repository platform in October 2018.

Figure 2 shows the repository home page.
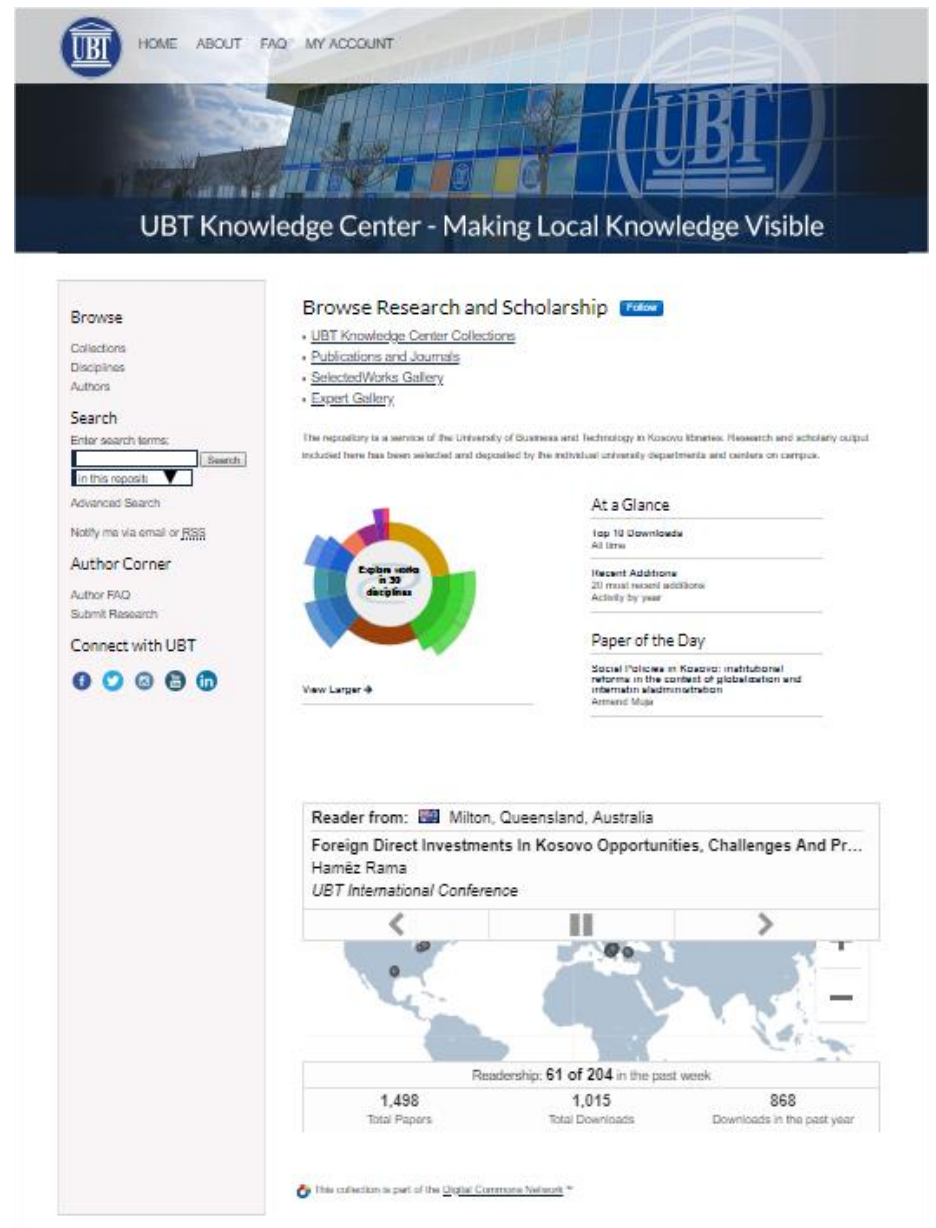

Figure 2. UBT Knowledge Center homepage, February 2019, https://knowledgecenter.ubtuni.net/

Beginning in October 2018, content was selected for upload to the repository based on critical collections identified by the University administration. Papers from the UBT International Conference, the International Journal of Business and Technology, and student Masters Theses 
were deemed priorities. These significant collections constitute knowledge generated and published by UBT. Their inclusion thus promotes the visibility of research generated and now hosted by UBT. Each record has a digital object identifier (DOI) assigned to it, creating a persistent identifier and confirming author and institutional quality. UBT's institutional repository is the first in the country to assign DOls to published records, which is a source of considerable pride for the university.

As previously stated, student recommendations from the 2018 course informed the UBT knowledge repository vision and its subsequent platform selection. For instance, students suggested multiple content recommendations and platform functionalities, which are available in the selected Digital Commons environment, such as:

- Content

- Open educational resources (OER)

- Digitized books

- Academic essays (by students)

- Journal and conference papers (by faculty)

- Functionality

- Categorized structure of projects

- Designed for continuation of study/class project development

○ Anti-plagiarism checker

Within the bepress environment, all suggested content is possible and all but one suggested feature/function is offered. For instance, journal articles, conference papers, student theses, student course projects, and university newsletters offer core UBT content in the Knowledge Center. Digitized books and OER will be added, as they become available. The proposed functionality, "categorized structure of projects", is the focus of on-going discussions to foster best practice in user experience. While a built in "anti-plagiarism checker" is not included in the bepress environment, contributions can be checked prior to upload in the UBT Knowledge Center using the institutional subscription to the software Turnitin, a commercial product that provides plagiarism detection.

Regarding the second suggested functionality, proposing that the repository is "designed for continuation of study/class project development", this need highlights the cyclical nature of the research process at any institution of higher education. It is less a functionality needed in the system, though the bepress system can certainly accommodate it, than it is an academic mindset which fosters knowledge creation for future knowledge extraction and expansion. By creating assignments which build on past work in course learning, students are allowed to explore further and deeper, utilizing the work of their peers and professors. Hence, creating the fourth category of Informed Learning - information curation and knowledge management served to bridge from categories 1-3 to reach 5-7. Concepts 5 and 6 , in particular, stress the need to share and build upon information for future knowledge creation (again, see Appendix for a full definition of Informed Learning concepts). For UBT and the Kosovo nation of which it is a part, creation and management activities foster forward movement, as a university and as a 
nation, through "systemic progression from concept to design to implementation and transformation - to animate creativity and innovation, accelerate adoption and adaption, and amplify experience and knowledge" (Somerville, Mirijamdotter, Bruce, Stoodley, \& Pireva, 2018).

\section{Concluding Reflections}

This paper describes an inclusive approach for co-design of holistic systems for enabling information literacy, as illustrated in the UBT Knowledge Center institutional repository at University for Business and Technology, Kosovo. The enactment process was informed by the theoretical construct of Informed Systems and guided by the Information Experience Design (IXD) method.

Both Informed Systems and IXD have roots in Informed Learning theory, a conceptualization of information literacy that acknowledges learning through experiencing information use in a range of different ways. As a result, implementation of Informed Systems through an IXD approach enacts informed learning and, hence, information literacy. Therefore, systems initiatives such as the UBT Knowledge Center, which emerge from the Informed Learning concept, are considered enablers of information literacy systems.

In this Kosovo example, course activities, user research, and design projects fostered exploration and enactment of the ACRL Framework Information literacy concepts, which recognize "the reflective discovery of information, the understanding of how information is produced and valued, and the use of information in creating new knowledge and participating ethically in communities of learning" (p. 8). Exploration of variation in information use prepared students serving as systems designers to adopt and adapt Information Experience Design principles in their own practice, through heightened awareness of their own information experience and that of others. Further, students were especially motivated to design systems to advance the information awareness and information experience of the systems' end users, thereby extending information literacy during system design and within designed systems.

While the seven categories of Informed Learning frame Informed Systems co-design aspirations, the context of local scholarship in a higher education setting of a transition nation, with a strong commitment to workplace readiness, required a high impact approach, which enabled knowledge production for social good. Therefore, students were eager to exceed their individual and collective information practices, which revealed the presence of only three informed learning theory categories, to accelerate information curation and knowledge management. This fourth Informed Learning category bridges to the more advanced categories of knowledge construction and worldview transformation, collegial sharing and knowledge extension, and professional wisdom and workplace learning. Further IXD research and design is needed to integrate these other information experiences into the UBT Knowledge Center local scholarship environment, to generate a truly robust enabler of information literacy.

This Knowledge Center research and development initiative completes a full circle of theorypractice-theory around the theoretical construct of Informed Systems. Through practical 
implementation in the real world, the paper also intentionally furthers the articulation of Informed Systems, which adds to its theoretical robustness. The paper illustrates how the implementation of Informed Systems can be explained through an Informed Learning (information) lens, in contrast to earlier North American implementations which privileged the contribution of Soft Systems Methodology (systems). This Kosovo example is further distinguished by the intentional integration of IXD, which showed how to enact Informed Systems with an emphasis on the information aspect.

Finally, the UBT Knowledge Center illustrates the efficacy of adopting and adapting high level theory through successful transfer of theory-to-practice, through research into practice and then back again, to benefit the institution, the nation, the region, and beyond. "In this way, the Knowledge Center initiative acknowledges the University's continuing responsibility to foster democratic civil society and regional economic growth as well as further smart business practices and higher education efficiencies, through knowledge sharing for knowledge generation" (Somerville, Mirijamdotter, Bruce, Stoodley, \& Pireva, 2018). Of practice-to-theory significance, intentional inclusion of Information Experience Design makes Informed Systems more robust through amplifying Informed Learning, during co-design activities and within designed systems. Doing so qualifies this Kosovo initiative as 'the first' to adapt Informed Systems to a transition nation's circumstances.

Note: The UBT Knowledge Center co-design initiative was made possible through generous funding and hospitality from University for Business and Technology, Kosovo; the Fulbright Commission, United States of America; Swedish Mobility, Linnaeus University, Sweden; Queensland University of Technology School of Information Systems, Brisbane, Australia; and University Libraries, University of the Pacific, California, United States of America.

\section{References}

Aliu, A., Bllacaku, A., \& Shkodra, V. (2017). Using Soft System Methodology as a Way to Enhance the Creation of UBT Knowledge Center. Pristina, Kosovo: University for Business and Technology student research paper.

Association of College \& Research Libraries. (2015). Framework for Information Literacy for Higher Education. Chicago, IL: Association of College \& Research Libraries/American Library Association.

Bruce, C. (2008). Informed learning. Chicago, IL: Association of College \& Research Libraries/American Library Association.

Bruce, C. S., Demasson, A., Hughes, H., Lupton, M., Maybee, C., Mirijamdotter, A., Sayyad Abdi, E., \& Somerville, M. M. (2017). Information literacy and informed learning: conceptual innovations for IL research and practice futures. The Journal of Information Literacy, 10 (June), 4 - 22. DOI: https://doi.org/10.11645/11.1.2184 
Bruce, C., \& Hughes, H. (2010). Informed learning: A pedagogical construct attending simultaneously to information use and learning. Library \& Information Science Research, 32, A2A8.

Bruce, C. S., Hughes, H., \& Somerville, M. M. (2012). Supporting informed learners in the $21^{\text {st }}$ century. Library Trends, 60(3), 522-545.

Bruce, C., Partridge, H., Hughes, H., Davis, K., \& Stoodley, I. (Eds.) (2014). Information Experience: Approaches to Theory and Practice. Library and Information Science, Vol. 9. Bingley, England: Emerald.

Checkland, P., \& Poulter, P. (2006). Learning for action: A short definitive account of Soft Systems Methodology and its use for practitioners, teachers and students. Chichester, England: John Wiley \& Sons.

Checkland, P., \& Poulter, P. (2010). Soft Systems Methodology. In Reynolds, M. \& Holwell, S. (eds.), Systems Approaches to Managing Change: A Practical Guide, London: The Open University, p. 191-242. Published in Association with Springer-Verlag London Limited. doi: 10.1007/978-1-84882-809-4_5

Gibney, M., Mirijamdotter, A., Somerville, M., Elm, P., \& Pireva, K. (2018). Evolution of a course instructional design elements and impacts. University for Business and Technology 7th International Conference on Education and Development, Pristina, Kosovo. http://knowledgecenter.ubt-uni.net/conference/2017/all-events/109/

Hajrizi, E., Mirijamdotter, A., Salavati, S., \& Somerville, M. M. (2017a). University for Business and Technology University Libraries and Knowledge Center. A concept paper. In: Fostering the As-A-Service Economy. International Conference Proceedings - Information Systems and Technology Innovations 2017 (ISTI 2017), Tirana, Albania. https://scholarlycommons.pacific.edu/cgi/viewcontent.cgi?referer=https://www.google.com/\& $\underline{\text { httpsredir }=1 \& \text { article }=1113 \& \text { context=libraries-pres }}$

Hajrizi, E., Somerville, M. M., \& Mirijamdotter, A. (2017b). The UBT Knowledge Center: A collaborative design approach. University for Business and Technology 6th International Conference on Education and Development, Durrës, Albania. http://scholarlycommons.pacific.edu/cgi/viewcontent.cgi?article=1117\&context=librari es-pres

Hajrizi, R., Ramadani, E., Bivolakum, R., Gosalci, D., \& Konushefei, J. (2017c). The creation of the Knowledge Center. Pristina, Kosovo: University for Business and Technology student research paper.

International Federation of Library Associations and Institutions. (2018). Gobal vision report summary: Top 10 highlights and opportunities. The Hague, The Netherlands: IFLA. Available: 
http://www.ifla.org/files/assets/GVMultimedia/publications/04-global-vision-report-summaryenglish.pdf

Kasemi, G., Lushta, B., \& Rexhepi, A. (2017). Applying Soft System Methodology to UBT Knowledge Center Case. Pristina, Kosovo: University for Business and Technology student research paper.

Mirijamdotter, A., Somerville, M. M., Salavati, S., \& Hajrizi, E. (2018). Making local knowledge visible: The case of the University for Business and Technology in Kosovo. Systems Research and Behavioral Science. doi:10.1002/sres.2566 https://onlinelibrary.wiley.com/doi/pdf/10.1002/sres.2566

Sayyad-Abdi, E. (2017). Information Experience Design in Bruce, C. S., Demasson, A., Hughes, H., Lupton, M., Maybee, C., Mirijamdotter, A., Sayyad Abdi, E., \& Somerville, M. M. (2017). Information literacy and informed learning: conceptual innovations for IL research and practice futures. The Journal of Information Literacy, 10 (June), 4 - 22. DOI: https://doi.org/10.11645/11.1.2184

Somerville, M. M. (2009). Working together: Collaborative practices for organizational learning. Chicago, IL: Association of College \& Research Libraries, American Library Association.

Somerville, M. M. (2014). Organizational systems, learning processes, and knowledge practices: Informed Systems methodology elements. International Conference Proceedings -Information Systems and Technology Innovations 2014 (ISTI 2014), Tirana, Albania.

Somerville, M. M. (2015a). Informed Systems: Essential elements for learning organizations. Inducting Modern Business Solutions: Information Systems and Technology Innovations Conference (ISTI-2015), Tirana, Albania. https://scholarlycommons.pacific.edu/libraries-pres/70/

Somerville, M. M. (2015b). Informed Systems: Organizational design for learning in action. Oxford, England: Chandos Publishing, a subsidiary of Elsevier.

Somerville, M. M. (2015c). Informed Systems for participatory organizations: Contributions from international researchers. In L. Finken, C. Mörtberg, \& A. Mirijamdotter, A. (Eds.) Organizing, Designing, and Managing: 18th Dilemmas International Research Conference, Växjö, Sweden. https://open.Inu.se/index.php/dilemmas/article/view/537

Somerville, M. M., Chaudhary, N., Mirijamdotter, A., \& Sayyad-Abdi, E. (2019). Informed Systems: 'Designing Together' for 'Learning Together', Journal of Library Administration, 59(1), 1-17. doi:10.1080/01930826.2018.1549403 
Somerville, M. M., Imhof, R., Bruce, C. S., \& Sayyad Abdi, E. (2017). Workplace information literacy: Co-designed information experience-centered systems and practices. European Conference on Information Literacy (ECIL 2017), Saint-Mali, France.

https://scholarlycommons.pacific.edu/cgi/viewcontent.cgi?article=1116\&context=libraries-pres

Somerville, M. M., \& Mirijamdotter, A. (2014). Information experiences in the workplace: Foundations for an Informed Systems Approach. In C. Bruce, H. Partridge, H. Hughes, K. Davis, \& I. Stoodley (Eds.), Information Experience: Approaches to Theory and Practice (pp. 203-220). (Library and Information Science, Vol. 9) Bingley, England: Emerald.

Somerville, M. M., Mirijamdotter, A., Bruce. C., Chaudhary, N., \& Salavati, S. (2018). Informed Systems: To advance organizational capacity and co-worker capability. Hawaii International Conference on Systems Sciences (HICSS-51), Hilo, Hawaii. https://scholarlycommons.pacific.edu/cgi/viewcontent.cgi?article=1139\&context=librari es-pres

Somerville, M. M., Mirijamdotter, A., Bruce, C., Stoodley, I., \& Pireva, K. (2018). From global theories to local practice and original knowledge: Learning the way through systems co-design. Information Literacy: From Practice to Research and Back Again Library Theory and Research Section joint session with Information Literacy Section, Transform Libraries. Transform Societies., International Federation of Library Associations and Institutions (IFLA), World Library and Information Congress, Kuala Lumpur, Malaysia. http://library.ifla.org/2152/1/116-somerville-en.pdf

University for Business and Technology. (2019a). UBT History. https://www.ubtuni.net/en/ubt-en/for-ubt/history/

University for Business and Technology. (2019b). RIIMS. http://riims.ubt-uni.net/

Xhemajli, V., Rexhepi, E., Sejdiji, D., \& Arifi, L. (2017). UBT Knowledge Center. Pristina, Kosovo: University for Business and Technology student research paper.

APPENDIX

Informed Learning Categories

1. Information and communication technologies: harnessing technology for information awareness, communication, and management,

2. Information sources: using information sources (including people) for workplace learning and action taking, 
3. Information and knowledge generation processes: developing personal practices or heuristics for finding and using information for novel situations,

4. Information curation and knowledge management: organizing and managing data, information, and knowledge for future professional needs,

5. Knowledge construction and worldview transformation: building knowledge through discovery, evaluation, discernment, and application,

6. Collegial sharing and knowledge extension: exercising and extending professional practices and knowledge bases to workplace insights, and

7. Professional wisdom and workplace learning: contributing to collegial learning through using information to learn to take better action to improve. (Bruce, Hughes, \& Somerville, 2012). 